\title{
PENGARUH RELIGIUSITAS TERHADAP PERILAKU SEKS PRANIKAH REMAJA DI PRODI D-III KEBIDANAN JURUSAN KEBIDANAN POLTEKKES KEMENKES MEDAN
}

\author{
Fitriyani Pulungan, Wardati Huamairah, Hanna Sri Yanti \\ Jurusan Kebidanan Poltekkes Kemenkes Medan
}

\begin{abstract}
Abstrak
Menurut data Riset Kesehatan Dasar (RISKESDAS) tahun 2010 ditemukan dari keseluruhan remaja berumur 10-24 tahun yang berstatus belum menikah adalah 86,7\%. Pada kelompok remaja dengan status belum kawin, sebanyak 3,0\% laki-laki dan perempuan 1,1 \% mengatakan pernah berhubungan seksual. Lebih lanjut dapat diketahui pula bahwa umur pertama berhubungan seksual sudah terjadi pada usia yang sangat muda, yaitu 8 tahun. Terdapat 0,5 persen perempuan telah melakukan hubungan seksual pertama kali pada usia 8 tahun, dan 0,1 persen pada laki-laki. Menurut Purnamasari (2004), agama merupakan salah satu sistem nilai yang dianut oleh individu karena agama berisi keyakinan dan kepercayaan yang dianut oleh individu yang kemudian diinternalisasikan kedalam dirinya yang akan mempengaruhi perilakunya seharihari. Penelitian ini merupakan penelitian analitik dengan pendekatan potong lintang (cross sectional), yang bertujuan menganalisis pengaruh religiusitas terhadap perilaku seksual dengan populasi adalah mahasiswi Jurusan Kebidanan Medan dengan jumlah sample 65 orang menggunakan analisis bivariate dan multivariate. Hasil penelitian ini menunjukkan ada pengaruh yang signifikan antara tingkat religiusitas terhadap perilaku seksual remaja dengan nilai $\mathrm{p}=0,001$, tidak ada pengaruh yang signifikan antara pekerjaan orang tua terhadap perilaku seksual remaja dengan nilai $\mathrm{p}=$ 0.402 , ada pengaruh yang signifikan antara tempat tinggal terhadap perilaku seksual remaja dengan nilai $p=$ 0,046 dan ada pengaruh yang signifikan antara media informasi terhadap perilaku seksual remaja dengan nilai $\mathrm{p}=0,010$. Diharapkan mahasiswa bergabung dalam organisasi disekolah atau berpartisipasi dalam aktivitas keagamaan seperti pengajian atau kegiatan hari besar keagamaan baik di lingkungan sekolah maupun di lingkungan masyarakat.
\end{abstract}

Kata kunci : Religiusitas, Perilaku Seks Pranikah, Remaja

\section{PENDAHULUAN}

Salah satu dampak dari Total Fertility Rate (TFR) dan Infant Mortality Rate (IMR) adalah perubahan struktur umur penduduk, diantaranya yaitu terjadinya peningkatan jumlah penduduk usia remaja. Berdasarkan data BPS, 2011, jumlah pemuda Indonesia (penduduk berusia 16 - 30 tahun) diperkirakan sebanyak 51,95 juta jiwa atau 25,69\% dari penduduk Indonesia yang berjumlah 241,13 juta jiwa. Dari data tersebut diketahui kelompok umur pemuda yang berusia 16 - 20 tahun sebesar 32,06\%. Jumlah remaja yang tidak sedikit ini merupakan potensi yang sangat berarti dalam melanjutkan pembangunan di Indonesia.

Berbagai upaya pembangunan untuk menggali potensi remaja dilakukan, sehingga menyebabkan perubahan pada kehidupan remaja. Apabila upaya pembangunan yang dilakukan seimbang dan proporsional tentu tidak akan menimbulkan masalah yang cukup berarti, akan tetapi adanya ketidakseimbangan upaya pembangunan yang dilakukan terutama terhadap remaja, akhirnya menimbulkan masalah bagi pembangunan itu sendiri. Salah satu masalahnya adalah terjadinya perubahan mendasar yang menyangkut sikap dan perilaku seksual pranikah di kalangan remaja (Notoatmodjo, 2007).

Perilaku seksual yang melanda remaja ini cenderung meningkat. Akibat dari segala dampak yang muncul seperti kehamilan di luar nikah, kawin muda, anakanak lahir diluar nikah, aborsi, penyakit menular seksual, depresi pada wanita yang terlanjur berhubungan seks dan lain sebagainya (Sarwono, 2012).

Sarwono (2012) mengutip pendapat Simkins (1984), sebagian dari tingkah laku itu memang tidak berdampak apa-apa, terutama jika tidak ada dampak fisik atau sosial yang dapat ditimbulkannya. Tetapi pada sebagian perilaku seksual yang lain, dapat terjadi kehamilan di luar nikah yang dampaknya bisa cukup serius, seperti perasaan bersalah, depresi, marah misalnya pada perempuan yang terpaksa menggugurkan kandungannya. Menurut Sarwono (2012) yang mengutip pendapat Sanderowitz dan Paxman (1985), bahwa akibat psikososial dapat timbul yaitu ketegangan mental, dan kebingungan akan peran sosial yang akan berubah jika seorang gadis tiba-tiba hamil dan akan mendapat 
cemoohan dan penolakan dari masyarakat sekitarnya. Kehamilan yang tidak diinginkan remaja tersebut dapat menjadikan remaja harus hamil pada usia muda.

Berdasarkan laporan WHO (2012), pada tahun 2008, ada 16 juta kelahiran dari ibu yang berusia 15-19 tahun, yang mewakili 11\% dari seluruh kelahiran yang ada di dunia. Sekitar 95\% dari kelahiran terjadi di negara berpenghasilan rendah dan menengah. Angka kelahiran global remaja ini telah menurun dari 60 per 1000 pada tahun 1990 menjadi 48 per 1000 pada tahun 2007, yang diawali dari 5 per 1000 wanita di Asia Timur menjadi 121 per 1000 di sub-Sahara Afrika pada tahun 2007. The World Bank (2010), juga mencatat laporan dari Millennium Development Goals (MDGs) (2010), dimana tingkat kelahiran remaja usia 15 - 19 tahun adalah 53 per 1000 kelahiran.

Data dari The National Survey of Family Growth (2011), yang mencatat aktivitas seksual, penggunaan kontrasepsi, kelahiran selama tahun 2006-2010,sekitar 43\% remaja perempuan(4,4 juta), dan sekitar 42\% remaja laki-laki (4,5 juta) telah melakukan hubungan seksual pra nikah setidaknya sekali. 78\% perempuan dan 85\% laki-laki menggunakan metode kontrasepsi pada seks pertama.

The National Youth Risk Behavior Survey (YRBS) (2012), memantau perilaku yang kesehatan berisikoyang berkontribusi terhadap penyebab utama kematian, cacat, dan masalah-masalah sosial di kalangan remaja di Amerika Serikat, dan diperoleh 47,4\% remaja sudah pernah melakukan hubungan seksual pada tahun 2011, dan sebanyak 6.2\% mengaku melakukan hubungan seksual sebelum umur 13 tahun.

Menurut data BPS, BKKBN, DEPKES RI, dan Macro Internasional, 2008, yang mencatat Indonesian Young Adult Reproductive Health Survey(IYARHS) tahun 2007, ditemukan 1\% wanita pernah melakukan hubungan seksual sedangkan pria 6\%. Beberapa responden ditanya alasan melakukan hubungan seksual pertama mereka. Keingintahuan tampaknya menjadi alasan utama untuk berhubungan seks yaitu 45\%, dan laki-laki lebih mungkin dibandingkan perempuan untuk menyebutkan alasan ini yaitu masing-masing sebanyak 51\% dan7\%.

Berdasarkan survei tersebut juga diketahui kebanyakan wanita dan laki-laki mulai berpacaran pada usia15-17, dengan sedikit lebih tinggi proporsi bagi perempuan daripada laki-laki masing-masing 43\% dan $40 \%$. Ini menyiratkan bahwa inisiasi untuk berpacaran lebih cenderung terjadi pada usia yang lebih muda pada wanita dibandingkan pria. Sebanyak $24 \%$ wanita mengatakan bahwa mereka mulai berkencan sebelum mencapai usia 15, dibandingkan dengan 19 persen lakilaki. Para responden juga ditanya jenis kegiatan yang mereka lakukan ketika kencan, termasuk berpegangan tangan, berciuman, dan petting, dan diketahui bahwa memegang tangan adalah yang paling umum dilakukan yaitu $68 \%$ pada perempuan dan 69\% pada laki-laki, berciuman laki-laki $41 \%$ dan perempuan 27 persen,dan yang melakukan petting laki-laki 27\% dan perempuan 9\%.

Menurut data Riset Kesehatan Dasar (RISKESDAS) tahun 2010 ditemukan dari keseluruhan remaja berumur 10-24 tahun yang berstatus belum menikah adalah 86,7\%. Pada kelompok remaja dengan status belum kawin, sebanyak 3,0\% laki-laki dan perempuan 1,1 \% mengatakan pernah berhubungan seksual. Lebih lanjut dapat diketahui pula bahwa umur pertama berhubungan seksual sudah terjadi pada usia yang sangat muda, yaitu 8 tahun. Terdapat 0,5 persen perempuan telah melakukan hubungan seksual pertama kali pada usia 8 tahun, dan 0,1 persen pada laki-laki.

Hasil penelitian di sejumlah kota besar di Indonesia menunjukkan sekitar 20\%-30\% remaja mengaku pernah melakukan hubungan seks (Priono, 2008).Di Jakarta, menurut Riset Strategi Nasional Kesehatan Remaja yang dilakukan oleh Departemen Kesehatan tahun 2005 menyebutkan 5,3 \% pelajar SMA di Jakarta pernah berhubungan seks. Survei yang dilakukan BKKBN tahun 2008 menyebut 63\% remaja di beberapa kota besar di Indonesia telah melakukan seks pra nikah (Utami, 2010).

Akibat lain yang dapat terjadi dari perilaku seksual remaja ini menurut Sarwono (2012) adalah terganggunya kesehatan dan risiko kehamilan serta kematian bayi yang tinggi serta munculnya penyakit infeksi menular seksual (IMS). Berdasarkan data BPS, BKKBN, DEPKES RI, dan Macro Internasional (2008), melalui Indonesian Demographic and Health Survey tahun 2007, mencatat Angka Kematian Ibu (AKI) 228/100.000 kelahiran hidup, Angka Kematian Bayi (AKB) 34/1000 KH dan Angka Kematian Neonatus (AKN) 19/1000 kelahiran hidup, hal ini masih jauh dari target MDGs tahun 2015 dimana AKI dan AKB di Indonesia masih cukup tinggi dibandingkan dengan Negara ASEAN lainnya. Penyebabnya antara lain tingginya angka kematian akibat komplikasi pada waktu hamil dan bersalin, aborsi tidak aman, PMS dan kanker reproduktif.

Remaja indonesia saat ini sedang mengalami perubahan sosial yang cepat dari masyarakat tradisional menuju masyarakat modern, yang juga mengubah normanorma, nilainilai dan gaya hidup mereka (Suryoputro, 2006). Masalah agama belum menjadi upaya sungguhsungguh dari orang tua dan guru terhadap diri remaja. Padahal saat ini banyak orang-orang yang berusaha agar agama remaja makin tipis. Sebagian dari mereka sudah termakan kampanye barat dengan meniru gaya hidup mereka yang bebas terutama hubungan perempuan dengan laki-laki, seperti pergaulan bebas atau seks bebas (Willis, 2010).

Menurut Yuhanita (2011) yang mengutip Angker (1997), terdapat beberapa faktor yang menyebabkan terjadinya perilaku seksual pranikah yaitu faktor misspersepsi terhadap pacaran, faktor religius dan faktor kematangan biologis. Berdasarkan contoh kasus di atas, faktor religius memegang peranan penting munculnya perilaku seksual pranikah pada remaja.

Berdasarkan hasil penelitian Idayanti (2002) diketahui bahwa ada hubungan negatif yang sangat signifikan antara religiusitas dengan perilaku seksual remaja yang sedang pacaran, dimana semakin tinggi religiusitas maka perilaku seksual semakin rendah, dan sebaliknya (Idayanti, 2002).

Berbeda dengan hasil penelitian Azizah (2006) terdapat perbedaan perilaku moral yang signifikan dan 
tidak terdapat perbedaan religiusitas antara siswa berlatar belakang pendidikan umum dan siswa berlatar belakang pendidikan agama; dimana siswa berlatar belakang pendidikan umum mempunyai perilaku moral yang lebih tinggi daripada siswa berlatar belakang pendidikan agama.

Hasil penelitian Soetjiningsih (2006) menunjukkan bahwa faktor-faktor yang mempengaruhi perilaku seks pranikah remaja adalah hubungan orangtua remaja, tekanan negatif teman sebaya, pemahaman tingkat agama (religiusitas), dan eksposur media pornografi memiliki pengaruh yang signifikan, baik langsung maupun tidak langsung terhadap perilaku seksual pranikah remaja.

Menurut Purnamasari (2004), agama merupakan salah satu sistem nilai yang dianut oleh individu karena agama berisi keyakinan dan kepercayaan yang dianut oleh individu yang kemudian diinternalisasikan kedalam dirinya yang akan mempengaruhi perilakunya sehari-hari. Selanjutnya Purnamasari (2004) mengutip Staub (1978) menyatakan bahwa perilaku yang mampunyai konsekuensi positif terhadap orang lain pada umumnya diarahkan oleh tatanan dan nilai-nilai moral yang diajarkan oleh ajaran agamanya.

Menurut survey pendahuluan yang dilakukan, bahwa terdapat kasus pada seorang mahasiswa, dimana mahasiswa tersebut mengatakan bahwa dia sudah menjalin hubungan dengan seseorang selama lebih dari 3 tahun, dan sudah pernah melakukan hubungan layaknya suami istri dengan sang pacar. Perbuatan tersebut mereka lakukan di rumah kos.

Berdasarkan latar belakang diatas maka peneliti tertarik untuk meneliti pengaruh religiusitas terhadap pengetahuan remaja tentang perilaku seks pranikah di Prodi D-III Kebidanan Jurusan Kebidanan Poltekkes Kemenkes Medan tahun 2015.

\section{Permasalahan Penelitian}

Perilaku seksual yang melanda remaja ini cenderung meningkat. Pemahaman tingkat agama (religiusitas), dianggap dapat memengaruhi perilaku seksual pada remaja, sehingga permasalahan dalam penelitian ini adalah bagaimana pengaruh religiusitas terhadap perilaku seksual remaja pada Mahasiswa di Prodi D-III Kebidanan Jurusan Kebidanan Poltekkes Kemenkes Medan tahun 2015.

\section{TUJUAN}

Untuk mengetahui pengaruh religiusitas terhadap perilaku seks pranikah di Prodi D-III Kebidanan Jurusan Kebidanan Poltekkes Kemenkes Medan tahun 2015.

\section{MANFAAT PENELITIAN}

\section{Prodi DIII Kebidanan Medan}

Dapat dijadikan dasar dalam menambahkan materi pelajaran di mata kuliah agama, agar lebih menekankan pada pencegahan perilaku seksual remaja

2. Keluarga/Orang tua

Memberi pemahaman agama yang baik kepada remaja, agar dapat terhindar dari perilaku seksual remaja.
3. Remaja

Meningkatkan pemahaman agama agar dapat terhindar dari perilaku seksual

\section{Jenis Penelitian}

Jenis penelitian menggunakankuantitatif merupakan penelitian analitik dengan pendekatan potong lintang (cross sectional), yang bertujuan menganalisis pengaruh religiusitas terhadap perilaku seksual.

\section{Lokasi dan Waktu Penelitian}

Penelitian ini dilakukan di Prodi D-III Kebidanan Jurusan Kebidanan Medan Poltekkes Kemenkes Medan pada bulan Juli sampai Oktober 2015.

\section{Populasi dan Sampel}

Populasi dalam penelitian ini adalah seluruh mahasiswi Prodi D-III Kebidanan Jurusan Kebidanan Poltekkes Kemenkes Medan tingkat I dan II. Sampel pada penelitian ini adalah 65 orang, dengan pengambilan sampel menggunakan proportional random sampling yaitu suatu cara pengambilan sampel yang dilakukan apabila populasinya terdiri atas kelompok yang tidak homogen. Kemudian sampel akan dipilih secara acak dengan bantuan tabel acak

\section{HASIL}

\section{Analisis Univariat}

Berdasarkan pekerjaan orang tua dapat dilihat lebih banyak responden memiliki orang tua yang bekerja yaitu 44 responden atau 67,7\%, sedangkan sisanya tidak bekerja. Untuk lebih jelas dapat dilihat pada Tabel 5.1 berikut :

Tabel 5.1

Distribusi Berdasarkan Pekerjaan Orang Tua

Mahasiswa di Prodi DIII Kebidanan Poltekkes Kemenkes Medan Tahun 2015

\begin{tabular}{ccc}
\hline Pekerjaan & F & \% \\
\hline Bekerja & 44 & 67,7 \\
Tidak Bekerja & 21 & 32,3 \\
\hline
\end{tabular}

Tabel 5.2 menjelaskan tentang tempat tinggal remaja, dan diketahui paling banyak remaja tinggal di luar asrama yaitu 38 orang atau 58,5\%. Untuk lebih jelas dapat dilihat pada tabel berikut :

Tabel 5.2

Distribusi Berdasarkan Tempat Tinggal Mahasiswa di Prodi DIII Kebidanan Poltekkes Kemenkes Medan Tahun 2015

\begin{tabular}{ccc}
\hline Tempat Tinggal & F & \% \\
\hline Asrama & 27 & 41,5 \\
Luar Asrama & 38 & 58,5 \\
\hline
\end{tabular}

Berdasarkan variabel media informasi dapat dijelaskan bahwa lebih banyak responden sedikit terpapar media informasi yaitu sebanyak 33 orang atau $50,8 \%$. Untuk lebih jelas dapat dilihat pada Tabel 5.3berikut : 
Tabel 5.3

Distribusi Berdasarkan Media Informasi Mahasiswa di Prodi DIII Kebidanan Poltekkes Kemenkes Medan Tahun 2015

\begin{tabular}{ccc}
\hline Media Informasi & F & \% \\
\hline Banyak & 32 & 49,2 \\
Sedikit & 33 & 50,8 \\
\hline
\end{tabular}

Berdasarkan tingkat religiusitas diketahui bahwa lebih banyak responden memiliki tingkat religiusitas tinggi yaitu sebanyak 55 orang atau 84,6\%, sisanya memiliki tingkat religiusitas rendah. Untuk lebih jelas dapat dilihat pada Tabel 5.4 berikut :

\section{Tabel 5.4}

Distribusi Berdasarkan Tingkat Religiusitas Mahasiswa di Prodi DIII Kebidanan Poltekkes Kemenkes Medan Tahun 2015

\begin{tabular}{ccc}
\hline Tingkat Religiusitas & F & \% \\
\hline Tinggi & 55 & 84,6 \\
Rendah & 10 & 15,4 \\
\hline
\end{tabular}

Selanjutnya pada berdasarkan Tabel 5.4 dapat dijelaskan bahwa perilaku seksual remaja lebih banyak pada kategori rendah yaitu sebanyak 56 orang atau 86,2\%. Untuk lebih jelas dapat dilihat pada Tabel 5.5 berikut :

Tabel 5.5

Distribusi Berdasarkan Perilaku Seksual Mahasiswa di Prodi DIII Kebidanan Poltekkes Kemenkes Medan Tahun 2015

\begin{tabular}{ccc}
\hline Perilaku Seksual & F & \% \\
\hline Tinggi & 9 & 13,8 \\
Rendah & 56 & 86,2 \\
\hline
\end{tabular}

\section{Analisis Bivariat}

Analisis bivariat dilakukan untuk mengetahui pengaruh satu variabel independen terhadap variabel dependen menggunakan uji Chi-square pada tingkat kemaknaan $\alpha<0,05$.

\section{Pengaruh Variabel Independen (Religiusitas) Terhadap Perilaku Seksual}

Tabel 5.6 menjelaskan tentang hasil analisis bivariat, dan diketahui pengaruh religiusitas terhadap perilaku seksual didapat bahwa dari 10 responden yang religiusitas rendah terdapat $60,0 \%$ yang memiliki memiliki perilaku seksual tinggi. Terdapat 5,5\% responden yang religiusitas tinggi tetapi memiliki perilaku seksual yang tinggi. Hal ini menjelaskan bahwa terdapat perbedaan perilaku seksual antara responden dengan tingkat religiusitas tinggi dan responden dengan tingkat religiusitas rendah. Hasil uji statistik menunjukkan nilai $p=0,001$ artinya ada pengaruh yang signifikan antara tingkat religiusitas terhadap perilaku seksual remaja.
Tabel 5.6

Pengaruh Religiusitas Terhadap Perilaku Seksual Mahasiswa Prodi DIII Kebidanan Poltekkes Kemenkes Medan Tahun 2015

\begin{tabular}{ccccccccc}
\hline $\begin{array}{c}\text { Variabel } \\
\text { Independen }\end{array}$ & \multicolumn{3}{c}{ Perilaku Seksual } & & Total & $\boldsymbol{p}$ & $\chi^{2}$ \\
\cline { 1 - 7 } $\begin{array}{c}\text { Tingkat } \\
\text { Religiusitas }\end{array}$ & Tinggi & \multicolumn{2}{c}{ Rendah } & & & & \\
\hline Tinggi & 3 & 5,5 & 52 & 94,5 & 55 & 100 & 0,001 & 21,10 \\
Rendah & 6 & 60,0 & 4 & 40,0 & 10 & 100 & & 4 \\
\hline
\end{tabular}

Pengaruh Variabel Counfounding Terhadap Perilaku Seksual

Variabel Counfounding dalam penelitian ini adalah pekerjaan orang tua, tempat tinggal dan media informasi.

\section{Pengaruh Pekerjaan Orang Tua Terhadap Perilaku Seksual Mahasiswa}

Tabel 5.7 menjelaskan tentang hasil analisis bivariat, dan diketahui pengaruh pekerjaan orang tua terhadap perilaku seksual didapat bahwa dari 44 responden yang orang tuanya bekerja terdapat 11,4 \% yang memiliki perilaku seksual tinggi. Terdapat 19,0\% responden yang memiliki orang tua tidak bekerja tetapi memiliki perilaku seksual yang tinggi. Hal ini menjelaskan bahwa terdapat perbedaan perilaku seksual antara responden dengan orang tua bekerja dan responden dengan orang tua tidak bekerja. Hasil uji statistik menunjukkan nilai $p=0,402$ artinya tidak ada pengaruh yang signifikan antara pekerjaan orang tua terhadap perilaku seksual remaja.

Tabel 5.7

Pengaruh Pekerjaan Orang Tua Terhadap Perilaku Seksual Mahasiswa Prodi DIII Kebidanan Poltekkes Kemenkes Medan Tahun 2015

\begin{tabular}{|c|c|c|c|c|c|c|c|c|}
\hline Variabel & \multicolumn{4}{|c|}{ Perilaku Seksual } & \multicolumn{2}{|c|}{ Total } & \multirow[t]{2}{*}{$P$} & \multirow[t]{2}{*}{$\chi^{2}$} \\
\hline Pekerjaan & \multicolumn{2}{|c|}{ Tinggi } & \multicolumn{2}{|c|}{ Rendah } & & & & \\
\hline Orang Tua & f & $\%$ & f & $\%$ & f & $\%$ & & \\
\hline Bekerja & 5 & 11,4 & 39 & 88,6 & 44 & 100 & 0,40 & 0,70 \\
\hline Tidak Bekerja & 4 & 19,0 & 17 & 81,0 & 21 & 100 & 2 & 4 \\
\hline
\end{tabular}

Pengaruh Tempat Tinggal Terhadap Perilaku Seksual Mahasiswa

Tabel 5.8 menjelaskan tentang hasil analisis bivariat, dan diketahui pengaruh tempat tinggal terhadap perilaku seksual didapat bahwa dari 38 responden yang tinggal di luar asrama terdapat 21,1\% yang memiliki perilaku seksual tinggi. Terdapat 3,7 \% responden yang tinggal di asrama tetapi memiliki perilaku seksual yang tinggi. Hal ini menjelaskan bahwa terdapat perbedaan perilaku seksual antara responden yang tinggal di asrama dan responden yang tinggal di luar asrama. Hasil uji statistik menunjukkan nilai $p=0,046$ artinya ada pengaruh yang signifikan antara tempat tinggal terhadap perilaku seksual remaja. 
Tabel 5.8

Pengaruh Tempat Tinggal Terhadap Perilaku Seksual Mahasiswa Prodi DIII Kebidanan Poltekkes Kemenkes Medan Tahun 2015

\begin{tabular}{|c|c|c|c|c|c|c|c|c|}
\hline Variabel & \multicolumn{4}{|c|}{ Perilaku Seksual } & \multicolumn{2}{|c|}{ Total } & \multirow[t]{3}{*}{$p$} & \multirow[t]{3}{*}{$\chi^{2}$} \\
\hline \multirow{2}{*}{$\begin{array}{c}\text { Tempat } \\
\text { Tinggal }\end{array}$} & Tinggi & & ndal & & \multirow[b]{2}{*}{ f } & \multirow[b]{2}{*}{$\%$} & & \\
\hline & f & $\%$ & $f$ & $\%$ & & & & \\
\hline Asrama & 1 & 3,7 & 26 & 96,3 & 27 & 100,0 & 0,046 & 3,983 \\
\hline $\begin{array}{c}\text { Luar } \\
\text { Asrama }\end{array}$ & 8 & 21,1 & 30 & 78,9 & 38 & 100,0 & & \\
\hline
\end{tabular}

\section{Pengaruh Media Informasi Terhadap Perilaku} Seksual Mahasiswa

Tabel 5.9 menjelaskan tentang hasil analisis bivariat, dan diketahui pengaruh media informasi terhadap perilaku seksual didapat bahwa dari 32 responden yang terpapar media informasi banyak terdapat 25,0 \% yang memiliki perilaku seksual tinggi. Terdapat 3,0 \% responden yang terpapar media informasi sedikit tetapi memiliki perilaku seksual yang tinggi. Hal ini menjelaskan bahwa terdapat perbedaan perilaku seksual antara responden yang terpapar media informasi banyak dan responden yang terpapar media informasi sedikit. Hasil uji statistik menunjukkan nilai $p=0,010$ artinya ada pengaruh yang signifikan antara media informasi terhadap perilaku seksual remaja.

\section{Tabel 5.9}

Pengaruh Media Informasi Terhadap Perilaku Seksual Mahasiswa Prodi DIII Kebidanan Poltekkes Kemenkes Medan Tahun 2015

\begin{tabular}{|c|c|c|c|c|c|c|c|c|}
\hline $\begin{array}{c}\text { Variabel } \\
\text { Independen }\end{array}$ & \multicolumn{4}{|c|}{$\begin{array}{c}\text { Perilaku } \\
\text { Seksual }\end{array}$} & \multirow{2}{*}{\multicolumn{2}{|c|}{ Total }} & \multirow{2}{*}{\multicolumn{2}{|c|}{$\gamma^{2}$}} \\
\hline \multirow{2}{*}{$\begin{array}{c}\text { Media } \\
\text { Informasi }\end{array}$} & & iggi & Ren & dah & & & & \\
\hline & f & $\%$ & f & $\%$ & f & $\%$ & & \\
\hline Banyak & 8 & 25 & 24 & 75 & 32 & 100 & 0,010 & 6,573 \\
\hline Sedikit & 1 & 3 & 32 & 97 & 33 & 100 & & \\
\hline
\end{tabular}

\section{Analisis Multivariat}

Analisis multivariat menggunakan analisis regresi logistik berganda. Sebelum melakukan analisis multivariat maka dilakukan terlebih dahulu pemilihan variabel yang menjadi kandidat model multivariat. Variabel yang menjadi kandidat multivariat adalah variabel independen dengan nilai $\mathrm{p}<0,25$ dalam analisis bivariat. Pada Tabel 5.10 diketahui bahwa yang masuk menjadi kandidat model yaitu variabel religiusitas, tempat tinggal, dan media informasi.

Tabel 5.10 Pemilihan Kandidat Model untuk Tahap Pemodelan Multivariat

\begin{tabular}{clc}
\hline No & Variabel & $\boldsymbol{P}$ \\
\hline 1. & Religiusitas & $0,001^{*}$ \\
2. & Pekerjaan Orang Tua & 0,402 \\
3. & Tempat Tinggal & $0,046^{*}$ \\
4. & Media Informasi & $0,010^{*}$ \\
\hline *: variabel yang masuk model &
\end{tabular}

Selanjutnyadilakukan pemeriksaan kolinearitas antar semua variabel yang masuk dalam kandidat model multivariat. Hasil analisis menunjukkan bahwa ada hubungan antara tempat tinggal dan media, sehingga variabel-variabel tersebut tidak boleh dalam satu model, oleh karena itu alternatif model yang dapat dibentuk dapat dilihat pada Tabel 5.11 berikut :

Tabel 5.11 Alternatif Model Regresi Logistik

\begin{tabular}{clccc}
\hline $\begin{array}{c}\text { Alternatif } \\
\text { Model }\end{array}$ & Fungsi & $\begin{array}{c}\text { Nil } \\
\text { ai p }\end{array}$ & $\chi^{2}$ & $\begin{array}{c}\text { Percen } \\
\text { tage } \\
\text { Correc } \\
\boldsymbol{t}\end{array}$ \\
\hline Model 1 & Perilaku & 0,00 & 20,7 & 90,8 \\
& Seksual = f & 1 & 81 & \\
& (Religiusitas & & & \\
& , Media & & & \\
& Informasi) & & & \\
\hline Model 2 & Perilaku & 0,00 & 15,5 & 89,2 \\
& Seksual = f & 1 & 35 & \\
& (religiusitas, & & & \\
& tempat & & & \\
& tinggal) & & & \\
\hline & & & &
\end{tabular}

Karena nilai $\chi^{2}$ lebih besar pada model 1 , maka sebagai model analisis multivariat dipilih model 1 dimana perilaku seksual $=\mathrm{f}$ (religiusitas, media informasi). Selanjutnya dilakukan analisis regresi logistik ganda dengan metode backward, yaitu memasukkan semua variabel independen ke dalam model dan variabel yang tidak berpengaruh secara otomatis akan keluar dari model.

Kemudian dilakukan pemeriksaan interaksi pada alternatif model yang terpilih. Ternyata tidak ada interaksi antara religiusitas dan media informasi, dilihat dari nilai p variabel interaksi $>0,05$, seperti yang dapat dilihat pada Tabel 5.12 berikut :

Tabel 5.12 Hasil Uji Interaksi

\begin{tabular}{lrrrrr}
\hline Variabel & B & P & Exp (B) & \multicolumn{2}{c}{ 95\% CI } \\
\cline { 5 - 7 } & & & & Lower & $\begin{array}{r}\text { Uppe } \\
\text { r }\end{array}$ \\
\hline Religiusitas & 3,278 & 0,001 & 26,528 & 3,846 & $\begin{array}{r}182,9 \\
71\end{array}$ \\
& & & & & 123,5 \\
Media & 2,393 & 0,053 & 10,946 & 0,970 & 06 \\
$\begin{array}{l}\text { Informasi } \\
\begin{array}{l}\text { Religiusitas } \\
\text { *Media }\end{array}\end{array}$ & $-17,601$ & 0,998 & 0,001 & 0,000 & \\
Constant & $-2,088$ & 0,001 & 0,011 & & \\
\hline
\end{tabular}

Model akhir dari analisis multivariat yang dapat dilihat pada Tabel 4.14 berikut :

Tabel 5.13 Hasil Analisis Regresi Logistik

\begin{tabular}{lllrrr}
\hline Variabel & B & P & Exp (B) & \multicolumn{2}{c}{ 95\% CI } \\
\cline { 5 - 6 } & & & & Lower & Upper \\
\hline Religiusitas & 3,278 & 0,001 & 26,528 & 3,846 & 182,971 \\
Media & 2,393 & 0,053 & 10,946 & 0,970 & 123,506 \\
Informasi & $-4,515$ & 0,001 & 0,011 & & \\
Constant & & &
\end{tabular}

Berdasarkan Tabel 5.13 di atas terlihat nilai p untuk masing-masing variabel $<0,005$, hal tersebut mengindikasikan bahwa model adalah signifikan. Maka model akhir regresi logistik ganda terdiri dari religiusitas dan media informasi. 
Kemudian dilakukan pemeriksaan confounding yaitu mengevaluasi variabel media informasi yang diduga sebagai variabel confounder dengan membandingkan koefisien atau OR variabel religiusitas pada model regresi logistik dengan atau tanpa variabel media informasi. Jika perbedaan koefisien tersebut besar ( $>10 \%$ ) berarti variabel tersebut merupakan konfounder untuk variabel paritas. Hasil dapat dilihat pada Tabel 5.14 berikut :

Tabel 5.14 Pemeriksaan Counfounding

\begin{tabular}{lccc}
\hline \multicolumn{1}{c}{ Persamaan } & Exp B & 95\% CI & $\begin{array}{c}\Delta \text { Exp } \\
\text { B }\end{array}$ \\
\hline Perilaku Seksual $=-$ & 3,258 & $4.660 ;$ & \\
2,853+26,000 & & 145.053 & \\
(Religiusitas) & & & 2,03 \\
Perilaku Seksual = - 3,278 & $3.846:$ & \\
4,515+26,528 & & 182.971 & \\
(Religiusitas) $+10,946$ & & & \\
\hline
\end{tabular}

Setelah dilakukan pemeriksaan counfounding , diketahui bahwa perbedaan OR variabel religiusitas pada model regresi logistik dengan atau tanpa variabel media informasi sebesar 2,03\% < 10\%, maka variabel media informasi bukan merupakan variabel confounder. Namun, walaupun variabel media informasi bukan merupakan confounder tetapi tetap dimasukkan ke dalam model regresi logistik ganda karena secara substansi ilmu media informasi memengaruhi perilaku seksual, sehingga model akhir regresi logistik ganda dapat dilihat pada Tabel 5.15 berikut :

Tabel 5.15 Model Akhir Regresi Logistik Ganda Pengaruh Religiusitas terhadap Perilaku Seksual Remaja di Prodi DIII Kebidanan Jurusan Kebidanan Medan Tahun 2015

\begin{tabular}{llrrrr}
\hline Variabel & B & P & Exp (B) & \multicolumn{2}{c}{ 95\% CI } \\
\cline { 5 - 6 } & & & & Lower & Upper \\
\hline Religiusitas & 3,278 & 0,001 & 26,528 & 3,846 & 182,971 \\
Media & 2,393 & 0,053 & 10,946 & 0,970 & 123,506 \\
Informasi & & & & \\
Constant & $-4,515$ & 0,001 & 0,011 & & \\
\hline
\end{tabular}

Berdasarkan hasil analisis tersebut, maka persamaan regresinya dapat ditulis sebagai berikut:

Dengan model persamaan regresi yang diperoleh, maka kita dapat suatu gambaran besar probabilitas perilaku seksual yaitu jika remaja memiliki religiusitas rendah, dan media informasi banyak, maka nilai probabilitas perilaku seksual sebesar $76 \%$ dan sebaliknya jika remaja memiliki religiusitas tinggi dan media informasi sedikit, maka nilai probabilitas perilaku seksual sebesar 1,08\%, sisanya dipengaruhi oleh variabel lain yaitu tempat tinggal.

\section{PEMBAHASAN}

\section{Pengaruh Variabel Independen (Religiusitas) Terhadap Perilaku Seksual}

Terdapat perbedaan perilaku seksual antara responden dengan tingkat religiusitas tinggi dan responden dengan tingkat religiusitas rendah. Hasil uji statistik menunjukkan nilai $p=0,001$ artinya ada pengaruh yang signifikan antara tingkat religiusitas terhadap perilaku seksual remaja. Hal ini sesuai dengan hasil penelitian yang mengatakan bahwa religiusitas merupakan faktor lain yang mempengaruhi kecenderungan perilaku seksual. Individu yang memiliki religiusitas memiliki pemahaman yang baik terhadap nilai-nilai keagamaan yang kemudian terinternalisasi kedalam dirinya. Ismail (2009) mengemukakan bahwa perasaan-perasaan atau pengalaman keagamaan yang selalu muncul dalam diri individu menyebabkan timbulnya kontrol internal dalam dirinya sehingga dapat mencegah timbulnya perilaku-perilaku menyimpang yang dapat merugikan diri sendiri maupun orang lain. Konsep untuk menyayangi dan mencintai sesama yang terkandung dalam nilai-nilai agama akan dimaknai dengan baik oleh individu yang memiliki tingkat religiusitas yang baik.

Menurut Andisti (2008) semakin tinggi religiusitas maka semakin rendah perilaku seks bebasnya, dan sebaliknya semakin rendah religiusitas maka semakin tinggi perilaku seks bebasnya. Religiusitas yang tinggi, karena subjek sering mengikuti kegiatan-kegiatan kerohanian yang menanamkan nilai-nilai atau normanorma agama pada subjek penelitian. Selain itu dengan senang membaca ayat-ayat pada kitab suci mereka, sehingga mereka mengetahui larangan-larangan dan perintah-perintah Tuhan. Lingkungan sekitar juga memegang peranan penting dalam terbentuknya religiusitas yang tinggi di dalam diri subjek penelitian. Pengawasan yang dilakukan secara positif oleh pemilik kost dan masyarakat sekitar membuat subjek penelitian dapat mengendalikan diri dan menjauhkan diri untuk melakukan perilaku seks bebas.

Menurut Miftah A (2008) mengatakan bahwa semakin tinggi religiusitas maka semakin rendah perilaku seks bebasnya dan sebaliknya.

Soviani L (2012) menyatakan bahwa tingkat religiusitas pada diriremaja akan berpengaruh terhadap perilakunya. Apabila remaja memiliki tingkat religiusitas yang tinggi, maka remaja akan menunjukkan perilaku ke arah hidup yang religius pula, sebaliknya remaja yang memiliki tingkat religiusitas rendah.Pada prinsipnya individu yang meyakini agamanya dengan baik, maka individu tersebut akan berpegang teguh pada keyakinan ajaran agamanya.

Pemahaman adalah suatu proses, cara memahami cara mempelajari baik-baik supaya paham dan pengetahuan banyak. Pengertian pemahaman mencakup tujuan, tingkah laku, atau tanggapan mencerminkan sesuatu pemahaman pesan tertulis yang termuat dalam satu komunikasi.

Menurut Nana Sudjana, menyatakan bahwa pemahaman dapat dibedakan kedalam 3 kategori yaitu, tingkat terendah adalah pemahaman terjemahan, mulai dari menerjemahkan dalam arti yang sebenarnya, mengartikan dan menerapkan prinsip-prinsip, tingkat kedua adalah pemahaman penafsiran yaitu menghubungkan bagianbagian terendah dengan yang diketahui berikutnya atau 
menghubungkan beberapa bagian grafik dengan kejadian, membedakan yang pokok dengan yang tidak pokok. tingkat ketiga merupakan tingkat pemaknaan ektrapolasi.

Menurut Suke Silversius, menyatakan bahwa pemahaman dapat dijabarkan menjadi tiga yaitu: Pertama, Menterjemahkan (translation), pengertian menerjemahkan disini bukan saja pengalihan (translation), arti dari bahasa yang satu kedalam bahasa yang lain, dapat juga dari konsepsi abstrak menjadi suatu model, yaitu model simbolik untuk mempermudah orang mempelajarinya. Pengalihan konsep yang dirumuskan dengan kata-kata kedalam gambar grafik dapat dimasukkan dalam kategori menerjemahkan. Kedua, Menginterprestasi (interpretation), kemampuan ini lebih luas daripada menerjemahkan yaitu kemampuan untuk mengenal dan memahami ide utama suatu komunikasi. Dan Ketiga, Mengektrapolasi (Extrapolation), tidak lain dari menerjemahkan dan menafsirkan, tetapi lebih tinggi sifatnya. Dalam hal ini menuntut kemampuan intelektual yang lebih tinggi.

Menurut Kompasiana (2007), Religiusitas merupakan penghayatan agama seseorang yang menyangkut simbol, keyakinan, nilai dan perilaku yang didorong oleh kekuatan spiritual. Untuk mengukur religiusitas ada tiga dimensi dalam Islam yaitu, aspek akidah (keyakinan), aspek syariah (praktik agama, ritual formal), dan aspek akhlak (pengamalan dari akidah dan syariah). Masalah agama pada remaja sebenarnya terletak pada tiga hal, yaitu: Pertama, keyakinan dan kesadaran beragama. Keyakinan dan kesadaran beragama harus ditumbuhkan dengan sengaja sejak anak masih kecil. Dan yang paling penting lagi ialaha membiasakan perbuatanperbuatan yang terpuji seperti kasih sayang kepada saudara dan kepada orang lain sesama manusia, sopan-santun, jujur tak mau berbohong, taqwa, sabar, tawakal dan sebagainya.

Pada masa remaja kebiasaan-kebiasaan yang telah ditanamkan diwaktu kecil akan mengalami tantangan dengan adanya pemikiran rasional dan adanya kenyataan hidup orang dewasa yang dilihatnya amat bertentangan dengan keyakinan yang telah ia terima. Kedua, pelaksanaan ajaran agama secara teratur. Jika keyakinan beragama atau kesadaran beragama sudah tumbuh dengan subur, untuk melaksanakan ajaran agama dengan konsekuen akan lebih mudah. Terutama sekali harus dibina disiplin menjalankan ajaran agama semenjak anak usia dini, sehingga di masa remaja kebiasaan itu mudah berkembang. Disiplin dalam agama timbul oleh tiga hal, yaitu: pertama, pengaruh dan contoh dari orang tua yang juga disiplin menjalankan ajaran agamanya. Kedua, menanamkan rasa kesadaran iman di dalam hati remaja , sehingga ia merasa takut kepada Tuhan jika meninggalkan syari'at agamanya dan berbuat kejahatan. Ketiga, pengaruh lingkungan yang beragama.

Pemuda-pemuda diorganisir dalam kegiatankegiatan agama, sehingga mereka sendiri berpartisipasi di dalam mengurus semua kegiatan dan acara-acara agama. Kesadaran, disiplin dan mendarah dagingnya ajaran agama, akan membawa kepada perubahan sikap dan tingkah laku remaja kearah positif dan produktif. Ketiga, perubahan tingkah laku karena agama. Agama itu sebenarnya adalah pendidikan, dan ajaran agama dapat dikatakan alat pendidikan yang bisa mengubah tingkah laku manusia kearah yang diinginkan atau diridhoi Tuhan. Tingkah laku yang perlu ditumbuhkan kepada remaja ialah berbuat sesuatu adalah karena Tuhan, karena keinginan Tuhan, karena mengharapkan ridha Tuhan semata. Kuat lemahnya motif karena Tuhan amat banyak bergantung kepada situasi lingkungan.

Jika pengaruh pengaruh negatif lebih dominan, maka motif berbuat karena Tuhan akan dikalahkan. Pemahaman tingkat agama menunjukkan bahwa kemampuan remaja dalam memahami dan mengetahui tentang agama. Oleh karena itu, Masalah komitmen beragama atau religiusitas adalah masalah yang sangat individual dan pribadi. Dengan demikian, remaja sangat perlu meningkatkan keimanan dan ketaqwaan mereka sesuai dengan agama yang dianutnya, karena pemahaman agama yang dimiliki remaja dapat juga mempengaruhi mereka dalam berperilaku (Nur Aini, 2011).

\section{Pengaruh Pekerjaan Orang Tua Terhadap Perilaku Seksual Mahasiswa}

Pengaruh pekerjaan orang tua terhadap perilaku seksual didapat bahwa dari 44 responden yang orang tuanya bekerja terdapat $11,4 \%$ yang memiliki perilaku seksual tinggi. Terdapat 19,0 \% responden yang memiliki orang tua tidak bekerja tetapi memiliki perilaku seksual yang tinggi. Hal ini menjelaskan bahwa terdapat perbedaan perilaku seksual antara responden dengan orang tua bekerja dan responden dengan orang tua tidak bekerja. Hasil uji statistik menunjukkan nilai $p=0,402$ artinya tidak ada pengaruh yang signifikan antara pekerjaan orang tua terhadap perilaku seksual remaja.

Pekerjaan orangtua tidak memengaruhi perilaku seksual remaja karena menurut Adawiyah (2007) pemahaman religiusitas yang baik akan menumbuhkan perilaku yang baik karena remaja memerlukan kemampuan pemecahan masalah yang baik, sehingga remaja mampu menyelesaikan masalah mereka dengan efektif, dengan bantuan orangtua di rumah berupa pembekalan materi tentang pendidikan seks dan intelektual serta pendidikan spiritual (agama) maka remaja akan terhindar dari perilaku seks yang menyimpang.

\section{Pengaruh Tempat Tinggal Terhadap Perilaku Seksual Mahasiswa}

Dari 38 responden yang tinggal di luar asrama terdapat 21,1 \% yang memiliki perilaku seksual tinggi. Terdapat 3,7 \% responden yang tinggal di asrama tetapi memiliki perilaku seksual yang tinggi. Hal ini menjelaskan bahwa terdapat perbedaan perilaku seksual antara responden yang tinggal di asrama dan responden yang tinggal di luar asrama. Hasil uji statistik menunjukkan nilai $p=0,046$ artinya ada pengaruh yang signifikan antara tempat tinggal terhadap perilaku seksual remaja.

Hal ini sesuai dengan penelitian Miftah A (2008), yang mengatakan bahwa lingkungan sekitar memegang peranan penting dalam terbentuknya 
religiusitas yang tinggi bagi mahasiswa karena akan memberikan pengaruh positif dan negative.

\section{Pengaruh Media Informasi Terhadap Perilaku Seksual Mahasiswa}

Pengaruh media informasi terhadap perilaku seksual didapat bahwa dari 32 responden yang terpapar media informasi banyak terdapat 25,0 \% yang memiliki perilaku seksual tinggi. Terdapat 3,0 \% responden yang terpapar media informasi sedikit tetapi memiliki perilaku seksual yang tinggi. Hal ini menjelaskan bahwa terdapat perbedaan perilaku seksual antara responden yang terpapar media informasi banyak dan responden yang terpapar media informasi sedikit. Hasil uji statistik menunjukkan nilai $p=0,010$ artinya ada pengaruh yang signifikan antara media informasi terhadap perilaku seksual remaja.

Hal tersebut sesuai dengan hasil penelitian Khairunnisa.A (2013) bahwa media massa seringkali diimitasi oleh remaja dalam perilakunya sehari-hari, misalnya mahasiswa yang menonton film barat, mereka melihat perilaku seks itu menyenangkan dan dapat diterima oleh lingkungan. Hal ini pun diimitasi oleh mahasiswa tanpa memikirkan adanya perbedaan kebudayaan, nilai serta norma dalam lingkungan masyarakat yang berbeda.

\section{Analisis Multivariat}

Analisis multivariat dilakukan untuk menganalisis pengaruh variabel independen dan variabel confounding terhadap variabel dependen. Analisis multivariat menggunakan analisis regresi logistik berganda. Sebelum melakukan analisis multivariat maka dilakukan terlebih dahulu pemilihan variabel yang menjadi kandidat model multivariat. Variabel yang menjadi kandidat multivariat adalah variabel independen dengan nilai $\mathrm{p}<0,25$ dalam analisis bivariat. Pada Tabel 5.6 diketahui bahwa yang masuk menjadi kandidat model yaitu variabel religiusitas, tempat tinggal, dan media informasi.

Selanjutnya dilakukan pemeriksaan kolinearitas antar semua variabel yang masuk dalam kandidat model multivariat. Hasil analisis menunjukkan bahwa ada hubungan antara tempat tinggal dan media, sehingga variabel-variabel tersebut tidak boleh dalam satu model, oleh karena itu alternatif model yang dapat dibentuk.

Karena nilai $\chi^{2}$ lebih besar pada model 1, maka sebagai model analisis multivariat dipilih model 1 dimana perilaku seksual $=\mathrm{f}$ (religiusitas, media informasi). Selanjutnya dilakukan analisis regresi logistik ganda dengan metode backward, yaitu memasukkan semua variabel independen ke dalam model dan variabel yang tidak berpengaruh secara otomatis akan keluar dari model.

Kemudian dilakukan pemeriksaan interaksi pada alternatif model yang terpilih. Ternyata tidak ada interaksi antara religiusitas dan media informasi, dilihat dari nilai $\mathrm{p}$ variabel interaksi > 0,05,

Berdasarkan Tabel 5.15 di atas terlihat nilai p untuk masing-masing variabel $<0,005$, hal tersebut mengindikasikan bahwa model adalah signifikan. Maka model akhir regresi logistik ganda terdiri dari religiusitas dan media informasi.

Kemudian dilakukan pemeriksaan confounding yaitu mengevaluasi variabel media informasi yang diduga sebagai variabel confounder dengan membandingkan koefisien atau OR variabel religiusitas pada model regresi logistik dengan atau tanpa variabel media informasi. Jika perbedaan koefisien tersebut besar ( $>10 \%$ ) berarti variabel tersebut merupakan konfounder untuk variabel paritas.

Setelah dilakukan pemeriksaan counfounding , diketahui bahwa perbedaan OR variabel religiusitas pada model regresi logistik dengan atau tanpa variabel media informasi sebesar $2,03 \%<10 \%$, maka variabel media informasi bukan merupakan variabel confounder. Namun, walaupun variabel media informasi bukan merupakan confounder tetapi tetap dimasukkan ke dalam model regresi logistik ganda karena secara substansi ilmu media informasi memengaruhi perilaku seksual, sehingga model akhir regresi logistik ganda.

Dengan model persamaan regresi yang diperoleh, maka kita dapat suatu gambaran besar probabilitas perilaku seksual yaitu jika remaja memiliki religiusitas rendah, dan media informasi banyak, maka nilai probabilitas perilaku seksual sebesar $76 \%$ dan sebaliknya jika remaja memiliki religiusitas tinggi dan media informasi sedikit, maka nilai probabilitas perilaku seksual sebesar 1,08\%, sisanya dipengaruhi oleh variabel lain yaitu tempat tinggal.

Media informasi cetak dan elektronik sangat memengaruhi perilaku seksual remaja karena banyak pengaruh negatif dan positif yang diberikan oleh media. Hal tersebut sesuai dengan hasil penelitian Khairunnisa.A (2013) bahwa media massa seringkali diimitasi oleh remaja dalam perilakunya sehari-hari, misalnya mahasiswa yang menonton film barat, mereka melihat perilaku seks itu menyenangkan dan dapat diterima oleh lingkungan. Hal ini pun diimitasi oleh mahasiswa tanpa memikirkan adanya perbedaan kebudayaan, nilai serta norma dalam lingkungan masyarakat yang berbeda.

\section{KESIMPULAN}

1. Ada pengaruh yang signifikan antara tingkat religiusitas terhadap perilaku seksual remaja dengan nilai $p=0,001$.

2. Tidak ada pengaruh yang signifikan antara pekerjaan orang tua terhadap perilaku seksual remaja dengan nilai $p=0,402$.

3. Ada pengaruh yang signifikan antara tempat tinggal terhadap perilaku seksual remaja dengan nilai $p=$ 0,046 .

4. Ada pengaruh yang signifikan antara media informasi terhadap perilaku seksual remaja dengan nilai $p=0,010$.

5.Dengan model persamaan regresi yang diperoleh, maka kita dapat suatu gambaran besar probabilitas perilaku seksual yaitu jika remaja memiliki religiusitas rendah, dan media informasi banyak, maka nilai probabilitas perilaku seksual sebesar $76 \%$ 
dan sebaliknya jika remaja memiliki religiusitas tinggi dan media informasi sedikit, maka nilai probabilitas perilaku seksual sebesar 1,08\%, sisanya dipengaruhi oleh variabel lain yaitu tempat tinggal.

\section{SARAN}

1. Upaya yang dapat dilakukan mahasiswa untuk meningkatkan kegiatan religiusitas antara lainya itu dengan bergabung dalam organisasi disekolah atau berpartisipasi dalam aktivitas keagamaan seperti pengajian atau kegiatan hari besar keagamaan baik di lingkungan sekolah maupun di lingkungan masyarakat.

2. Diharapkan pada pihak sekolah dapat lebih banyak memberikan pelatihan-pelatihan dengan tujuan pembentukan konsep diri remaja yang baik dalam menanggapi fenomena-fenomena negative keremajaan seperti pendalaman pengetahuan tentang bagaimana menjadi remaja yang baik, pendidikan tentang pacaran dan pendidikan tentang bagaimana menghadapi permasalahan keremajaan

3. Orangtua tidak mentabukan pembicaran tentang seksualitas dengan anak remajanya, sehingga remaja dapat memperoleh informasi yang benar tentang seksualitas dengan orangtua.

4. Mahasiswa hendaknya menekan perilaku seks pranikah dan menjauhi media pornografi sehingga dapat mengendalikan dorongan negative dan merubahnya kearah yang positif sehingga tidak akan terjerumus kedalam perilaku seksual pranikah.

5. Peneliti selanjutnya diharapkan untuk mengkaji masalah ini dengan jangkauan yang lebih luas dengan menambah variable lain yang memungkinkan memiliki hubungan perilaku seksual pranikah, seperti pola asuh, konformitas, kepribadian dan konrol diri.

\section{DAFTAR PUSTAKA}

Badan Pusat Statistik, 2011, Statistik Pemuda Indonesia 2011, Subdirektorat Statistik Pendidikan Dan Kesejahteraan Sosial, Jakarta

Badan Penelitian Dan Pengembangan Kesehatan Kementerian Kesehatan RI, 2011, Hasil Riset Kesehatan Dasar (RISKESDAS) tahun 2010, Jakarta. .2010, Hasil Laporan World Development Indicators Millennium Development Goals 1990-2010, The World Bank Group.

Badan Pusat Statistik (BPS), BKKBN, DEPKES RI, Macro Internasional, 2008, Youth Reproduction Health Survey 2007, Calverton, Maryland, USA : BPS dan Macro Internasional .2008, Indonesian Demografi and Health Survey 2007, Calverton, Maryland, USA : BPS dan Macro Internasional.

Dinas Kesehatan Provinsi Sumatera Utara, 2011, Profil Kesehatan Provinsi Sumatera Utara tahun 2011, Medan
Department of Health and Human Service, 2012, National Youth Risk Behavior Survey (YRBS), Trends in the Prevalence of Sexual Behaviors and HIV Testing National YRBS: 1991-2011, Centers for Disease Control and Prevention.

Hidayat, A.A, 2007, Metode Penelitian Kebidanan dan Teknik Analisis Data, Jakarta Penerbit Salemba

Hidayah, I., P.,2010, Pengaruh Asertivitas Terhadap Prilaku Seksual Pranikah Pada Remaja Perempuan. Skripsi, Fakultas Psikologi, Universitas Sumatera Utara

Holdcroft, B., 2006, What Is Religiosity?Catholic EducationThe University of ToledoLourdes College.

Indrayani, Saepudin, A., 2008, Faktor-Faktor yang Berhubungan dengan Kehamilan Pranikah di Kalangan Pelajar di Desa Setianagara Kecamatan Cilimus Kabupaten Kuningan Tahun 2008, STIKES Kuningan Garawangi.

Kemenkes, 2010, Riset Kesehatan Dasar (RISKESDAS) tahun 2010, Jakarta

Khairunnisa.A, 2013, Hubungan Religiusitas dan Kontrol Diri dengan Perilaku Seksual Pranikah Remaja di MAN 1 Samarinda, e-Journal Psikologi.fisipunmul.org, 2013.

Miftah.A, 2008, Religiusitas dan Perilaku Seks Bebas pada Dewasa Awal, Jurnal Psikologi Volume 1, No.2 Juni 2008

Muadz, M. M., Syaefuddin., 2010, Keterampilan Hidup (Life Skills) dalam Program Penyiapan Kehidupan Berkeluarga bagi Remaja, Direktorat Remaja dan Perlindungan Hak-Hak Reproduksi, Jakarta. BKKBN

Nur Aini L, 2011, Hubungan Pemahaman Tingkat Agama(Religiusitas) dengan Perilaku Seks Bebas Pada Remaja di SMAN 1 Bangsal Mojokerto, Jurnal Keperawatan-Volume 01/Nomor 01/Januari 2011Desember 2011

Notoatmodjo, S. 2007, Promosi Kesehatan dan Ilmu Perilaku. Jakarta : Rineka Cipta

Sarwono, S.W.,2012, Psikologi Remaja, Edisi Revisi, Jakarta; Penerbit Rajawali Press.

Santrock, J.W., 2007, Remaja, Edisi Kesebelas, Jakarta ; Penerbit Erlangga.

Sovinia L, 2012, Hubungan antara Religiusitas dan Agresivitas, Fakultas Psikologi Universitas Diponegoro.

Suryoputro, A., Ford, N., J., Shaluliyah, Z., Social Learning Theory in Youth Sexual Behaviour Study in Central Java, Universitas Diponegoro, Fakultas Kesehatan Masyarakat, Semarang

World Health Organization, 2012, Preventing Early Pregnancy andPoor Reproductive OutcomesAmong Adolescents in Developing Countries, WHO 